DOI: $10.19195 / 0080-3626.60 .12$

KATARZYNA JAMROZIK

\title{
PROBLEMATYKA BADAŃ NAD JEDNODNIÓWKAMI W POLSCE PO 2008 ROKU
}

Kwestie terminologiczne. Przegląd najważniejszych bieżących publikacji o jednodniówkach.

SŁOWA KLUCZOWE: prasoznawstwo, efemerydy, druki ulotne i okolicznościowe, dokumenty życia społecznego

Ostatnie lata przyniosły znaczny wzrost zainteresowania drukami ulotnymi i okolicznościowymi - specyficzną grupą wydawnictw o charakterze informacyjnym i normatywnym, odzwierciedlających życie społeczne, zazwyczaj przeznaczonych dla osiągnięcia doraźnych celów praktycznych. Dokumenty te mają krótkotrwałą wartość użytkową, występują w różnych formach wydania i zazwyczaj nie są przeznaczone do handlu księgarskiego' ${ }^{1}$. Pojęciami stosowanymi zamiennie są: dokumenty życia społecznego, druki efemeryczne, efemerydy. Krzysztof Migoń wskazał typowe elementy i właściwości tych druków: mała, niesprecyzowana jednoznacznie objętość, zwarty tekst dotyczący życia społecznego, aktualność, okazjonalność, masowość, z reguły bezpłatne rozpowszechnianie ${ }^{2}$.

Warto przypomnieć, iż w październiku 2004 roku Instytut Informacji Naukowej i Bibliotekoznawstwa Uniwersytetu Wrocławskiego zorganizował międzynarodową konferencję naukową poświęconą temu rodzajowi wydawnictw. Plonem trzydniowych obrad był wydany w 2006 roku tom pokonferencyjny Druki ulotne i okolicznościowe - wartości i funkcje ${ }^{3}$. Badania nad różnymi typami efemeryd wciąż są aktywnie prowadzone przez pracowników Instytutu; w naj-

1 Aneta FIRLEJ-BUZON, Dokumenty życia społecznego w teorii i praktyce bibliotekarskiej w Polsce, Warszawa: Wydaw. SBP 2002, s. 36.

2 Krzysztof MIGOŃ, Bibliologia o drukach ulotnych i okolicznościowych, [w:] Druki ulotne i okolicznościowe - wartości i funkcje. Materiaty międzynarodowej konferencji naukowej, Wojnowice, 8-10 października 2004. Red. nauk. Krzysztof Migoń, Marta Skalska-Zlat, Anna Żbikowska-Migoń, przy współpr. Elżbiety Herden, Wrocław: Wydaw. Uniwersytetu Wrocławskiego 2006, s. 9-19.

3 Por. przyp. 2 
szerszym ujęciu problematykę dokumentów życia społecznego omówiła Aneta Firlej-Buzon, która także dokonała najpełniejszej analizy literatury przedmiotu ${ }^{4}$. W osobnej publikacji podjęła tematykę druków ulotnych z Dolnego Śląska, wykazując ich znaczną wartość informacyjną i wyjątkowość jako materiału badawczego $^{5}$. Wyłącznie jednodniówkom, jako specyficznemu typowi druków ulotnych i okolicznościowych, liczne prace poświęciła Małgorzata Korczyńska-Derkacz. W 2008 roku przedstawiła ona stan badań nad tymi wydawnictwami w artykule Jednodniówki jako typ dokumentów życia społecznego. Zarys problematyki badawczej ${ }^{6}$, będącym kompleksowym opracowaniem zagadnienia. Autorka poruszyła aspekty definicyjne, a w celu wykazania źródłowej wartości jednodniówek, w oparciu o Centralny Katalog Czasopism Polskich, przeprowadziła wieloaspektową ocenę materiału. Według chronologii wydania, języka, miejsca wydania, instytucji sprawczych oraz tematyki usystematyzowano kolejno 1344 dokumenty. Analiza każdej z grup pozwoliła na zaobserwowanie pewnych tendencji, znacznie ułatwiających orientację w obszernym zbiorze. Wyróżniła także podstawowe zagadnienia badawcze, dla których źródłem mogą być jednodniówki (badania typograficzne, badania życia społeczności lokalnych i środowiskowych, badania jednodniówek jako specyficznego typu wydawnictw, badania cech wydawniczych) oraz wykazała świadectwo naukowej wartości tych dokumentów. Niniejsza praca stanowi kontynuację, a w niewielkim stopniu również uzupełnienie tych badań.

Hasło ,jednodniówka” odnotowuje większość wydawnictw encyklopedycznych i słownikowych z zakresu bibliotekoznawstwa i informacji naukowej, a także niektóre słowniki językowe. Definicje są do siebie zbliżone, jednak ich przegląd pozwala na zaobserwowanie pewnych niuansów świadczących o nieostrości terminu. Ich przeglądu dokonała już M. Korczyńska-Derkacz we wspomnianym wyżej artykule, jednak warto zauważyć, iż wydany w 2011 roku Podręczny stownik bibliotekarza, opracowany przez Grzegorza Czapnika i Zbigniewa Gruszkę, opisuje jednodniówkę niemal identycznie jak Encyklopedia wiedzy o prasie, jako: „wydawnictwo podobne do czasopisma, lecz jednorazowe, najczęściej okolicznościowe (np. wydane w trakcie trwania zjazdu jakiejś organizacji), stające się często próbnym (pierwszym) numerem czasopisma". Definicję uzupełniają ekwiwalenty w językach obcych: w angielskim „one day's paper”; we francuskim „éphéméride”; w niemieckim „Eintagsblatt”; w rosyjskim „однодневная газета” (odnodnevna-

4 A. FIRLEJ-BUZON, op. cit., s. 19-56.

5 A. FIRLEJ-BUZON, Druki ulotne i okolicznościowe jako źródła do badań dziejów i kultury Dolnego Ślaska lat 1945-1956, Wrocław: Wydaw. Uniwersytetu Wrocławskiego 2013.

${ }^{6}$ Małgorzata KORCZYŃSKA-DERKACZ, Jednodniówki jako typ dokumentów życia społecznego. Zarys problematyki badawczej, Acta Universitatis Wratislaviensis. Bibliotekoznawstwo (27) 2008, s. 135-148. 
ja gazeta) ${ }^{7}$. Niestety odpowiedniki angielski i niemiecki budzą wątpliwości pod względem terminologicznym.

Termin „one day's paper” nie występuje w literaturze angielskiej ani amerykańskiej, nie odnotowują go podstawowe wydawnictwa słownikowe z zakresu bibliotekoznawstwa, jak Harrod's librarian's glossary i Elsevier's dictionary of library science, information, and documentation ${ }^{8}$, ani skupiające się na problematyce druków ulotnych i okolicznościowych ${ }^{9}$. Spotykamy się z nim jedynie w piśmiennictwie krajowym - głównie w anglojęzycznych streszczeniach i abstraktach artykułów. W istocie nie jest to ekwiwalent, lecz dosłowne tłumaczenie: one jeden, day — dzień, paper — gazeta, którego stosowanie, wygodne na gruncie polskim, staje się problematyczne w przypadku korzystania z literatury obcej.

Problemy te, przynajmniej częściowo, rozwiązuje norma PN-ISO 5127:2005. Informacja i dokumentacja. Terminologia. Nie odnotowuje ona ani hasła ,jednodniówka”, ani „one day’s paper”, znaleźć można natomiast angielski termin „ephemera”, definiowany jako: „documents produced for a specific event, or series of events, ceasing to serve their original purpose after a period of time or in another context"10. Odpowiednikiem francuskim jest „éphémères”"11, a polskim — „druk ulotny”, czyli: „,dokument wyprodukowany z okazji określonego wydarzenia lub serii wydarzeń, tracący swój pierwotny cel po pewnym czasie lub w innym kontekście"12.

Fakt, iż angielska „ephemera” jest najlepszym odpowiednikiem polskiej „jednodniówki” potwierdza także Stownik wyrazów obcych i terminów obcojęzycznych Władysława Kopalińskiego, w którym znajdujemy definicję efemerydy: „istota, rzecz, zjawisko nietrwałe, szybko przemijające; dawn. (pismo, gazeta) jednodniówka. - gr. ephếmeros ‘żyjący tylko jeden dzień; dzienny’, eph- 'na,

${ }^{7}$ Podręczny słownik bibliotekarza. Oprac. Grzegorz Czapnik, Zbigniew Gruszka przy współpr. Hanny Tadeusiewicz, Warszawa: Wydaw. SBP 2011, s. 127. Te same ekwiwalenty podają także: Helena WIĘCKOWSKA, Hanna PLISZCZYŃSKA, Podręczny słownik bibliotekarza, Warszawa: Państwowe Wydawnictwo Naukowe 1955, s. 77.

8 Elsevier's Dictionary of Library Science, Information, and Documentation, in Six Languages: English/American, French, Spanish, Italian, Dutch, and German. Ed. Willem E. Clason, Amsterdam-London-New York: Elsevier Scientific Publ. Co. 1973; Harrod's Librarians' Glossary of Terms Used in Librarianship, Documentation, and the Book Crafts, and Reference Book. 7th ed. Ed. Raymond J. Prytherch, Aldershot: Gower 1990.

9 Zob. Maurice RICKARDS, The Encyclopedia of Ephemera: a Guide to the Fragmentary Documents of Everyday Life for the Collector, Curator, and Historian, London: The British Library 2000.

10 PN-ISO 5127:2005. Informacja i dokumentacja. Terminologia, Warszawa 2005, s. 46. Por. „ephemera” [hasło w:] International Encyclopedia of Information and Library Science. Ed. by John Feather and Paul Sturges, London-New York: Routledge 1997, s. 134-136.

11 Ibidem, s. 46. Por. „éphémères publications” [hasło w:] Dictionnaire encyclopédique du livre. Vol. 2. Paris: Éditions du Cercle de la Librairie 2005, s. 89.

12 Ibidem, s. 46. 
do'; hēméra 'dzień”’13. Widać wyraźnie, iż ,jednodniówka” stanowi dokładne tłumaczenie źródłosłowu greckiego.

Dwujęzyczny słownik Eberharda Sauppe Dictionary of Librarianship odsyła od „ephemera” do niemieckiego terminu „Ephemera” ${ }^{4}$. „Eintagsblatt” zdaje się przypadkiem analogicznym do „one day's paper”, a hasła tego nie odnotowują wydawnictwa informacyjne ${ }^{15}$.

Brak ekwiwalencji świadczy o specyficznym charakterze jednodniówek i potwierdza, iż ten typ dokumentów nie jest znany w Europie Zachodniej. Wyjątkowość w skali międzynarodowej bez wątpienia podnosi ich rangę i wartość źródłową.

\section{PRZEGLĄD NAJWAŻNIEJSZYCH PUBLIKACJI O JEDNODNIÓWKACH}

Kwerenda przeprowadzona w Polskiej Bibliografii Bibliologicznej, uzupełniona szczegółowym przeglądem katalogów i bibliografii załącznikowych, pozwoliła na zgromadzenie 46 pozycji ściśle związanych z badaną problematyką.

Niniejszy przegląd otwierają opracowania o charakterze ogólnym. Halina Wojtysiak jednodniówki zaliczyła do grupy wydawnictw ciągłych i wprowadziła adekwatną typologię ${ }^{16}$. Zauważyła związki wydawania jednodniówek z sytuacją polityczną czasopism i działaniem cenzury, przytaczając konkretne tytuły zawieszanych czasopism - głównie dzienników i periodyków społeczno-politycznych - które były zastępowane cyklami jednodniówek. Opisała przykłady jednodniówek wydawanych jako próbne numery czasopism, ciągi jednodniówek pod wspólnym tytułem, zbiory jednodniówek pod indywidualnymi tytułami, lecz opracowane według jednolitego schematu typograficznego, opozycyjne wydawnictwa, które nie uzyskałyby legalizacji jako periodyki, cykle jednodniówek futurystycznych jako celowe łamanie konwencji i wybór formy wydawniczej w opozycji do czasopisma oraz jednodniówki dołączane jako dodatki do periodyków.

Problemowy charakter ma również opracowanie Ewy Dombek, poruszające zagadnienia trudności opracowania formalnego i katalogowania oraz rozproszenia jednodniówek w bibliografiach i katalogach ${ }^{17}$, jakie napotkała podczas prac nad

13 Władysław KOPALIŃSKI, Słownik wyrazów obcych i zwrotów obcojęzycznych z almanachem, wyd. 23, Warszawa: Wiedza Powszechna 1994, s. 139.

14 Eberhard SAUPPE, Dictionary of Librarianship, 2nd ed, München: K.G. Saur 1996, s. 253.

15 Brak hasła „Eintagsblatt” m.in. w: Elsevier's Dictionary of Library Science...; Harrod's Librarians' Glossary...; Lexikon des Bibliothekswesens, Hrsg. Horst Kunze, Gotthard Rück1, Bd. 1, Leipzig: Bibliographisches Institut 1974.

${ }^{16}$ Halina WOJTYSIAK, Jednodniówki jako osobliwy rodzaj wydawnictw ciagtych, EBIB (2) 2012, http://www.ebib.pl/images/stories/numery/129/129_wojtysiak.pdf [dostęp: 9 V 2016].

17 Te same zagadnienia, wsparte bogatą egzemplifikacją, autorka poruszyła w III rozdziale publikacji: Ewa DOMBEK, Potyczki bibliografa, czyli bibliografia od kuchni, Warszawa: Wydaw. SBP 2015. 
16 tomem Bibliografii polskiej 1901-1939, w całości poświęconemu jednodniówkom. Autorka podkreśliła ich wartość, pisząc:

Jednodniówki to niezmiernie interesujący typ wydawnictw, kryjący ogromny ładunek informacji o faktach, o których rzadko można przeczytać w wielkich monografiach. Ich wielkim atutem jest przede wszystkim aktualność. Oznaczone przez wydawców i redaktorów datą dzienną czy miesięczną są dokumentem chwili. To właśnie w takich wydawnictwach można znaleźć wiadomości o ludziach, wydarzeniach, organizacjach, o których pamięć przetrwała jedynie tam. Dzięki takim publikacjom można niejednokrotnie bezbłędnie ustalić losy konkretnych osób czy uściślić historię dotyczącą organizacji, stowarzyszeń, instytucji i najróżniejszych inicjatyw społecznych. I to największa ich wartość, gdyż za treść odpowiedzialni są autorzy bezpośrednio związani z opisywanymi wydarzeniami. Jednodniówki dają informację „,z pierwszej ręki”, więc też najbardziej godną zaufania ${ }^{18}$.

Znaczną część zebranej literatury przedmiotu stanowią opracowania pojedynczych tytułów, dobranych według indywidualnych zainteresowań badaczy ${ }^{19}$. Taki charakter ma publikacja Grzegorza Piotra Dudzika, który dokonał analizy ośmiostronicowej jednodniówki wydanej z okazji święta kupiectwa i rzemiosła chrześcijańskiego w Wołominie, wydanej 8 grudnia 1937 roku $^{20}$.

Sebastian Ławniczak zajął się jednodniówką „Wałeckie Wiadomości Wyborcze", wydaną z okazji wyborów do rad narodowych w 1958 roku przez Powiatowy Komitet Frontu Jedności Narodu w Wałczu - ogólnokrajowy ruch społeczno-polityczny pod patronatem PZPR ${ }^{21}$. Autor ograniczył się jednak tylko do przytoczenia jej fragmentów w formie obszernych cytatów, bez szczegółowej analizy zawartości. Podobne ujęcie cechuje artykuł Janusza Kuligowskiego „, Próba Sił”jednodniówka Okręgowego Związu Młodzieży w Mińsku Mazowieckim z 1920 r., który poświęcony został historii Związku Młodzieży Wiejskiej na terenie powiatu mińskiego do 1928 roku i jedynie uzupełniony przedrukiem trzydziestodwustro-

18 Ewa DOMBEK, Jednodniówki w „Bibliografii polskiej 1901-1939”, Bibliotekarz (6) 2012, s. $21-22$.

${ }^{19}$ Cztery tego typu publikacje opisała M. Korczyńska-Derkacz: Wiesław SONCZYK, Zapomniana jednodniówka studencka. Pierwsze koncepcje studiów dziennikarskich, Prasa Polska (11) 1976, s. 33-34; Halina STĘPIEŃ, O „Jednodniówce” monachijskiej. Niezauważony epizod z dziejów polskiego modernizmu, Rocznik Muzeum Mazowieckiego w Płocku (14) 1991, s. 85-120; Janusz KRĘŻEL, Mielecka jednodniówka świąteczna z 24 grudnia 1944 r., Rocznik Mielecki (6) 2003, s. 137-141; Katarzyna KULPIŃSKA, , Jednodniówka” monachijska (1897), [w:] eadem, Szata graficzna młodopolskich czasopism literacko-artystycznych, Warszawa 2005, s. 182-184. Zob. M. KORCZYŃSKA-DERKACZ, op. cit., s. 138-140.

20 Grzegorz P. DUDZIK, „Promień w Wołominie”: jednodniówka kupiectwa i rzemiosła chrześcijańskiego, Studia i Materiały do Dziejów Powiatu Wołomińskiego (3) 2007, s. 289-298.

21 Sebastian ŁAWNICZAK, ,Wałeckie Wiadomości Wyborcze”: jednodniówka Powiatowego Komitetu Frontu Jedności Narodu w Watczu z 1958 roku, Studia i Materiały do Dziejów Ziemi Wałeckiej (1) 2010, s. 131-144. 
nicowej jednodniówki, której zawartości nie przeanalizowano ${ }^{22}$. Fragmentaryczne informacje dotyczą wyłącznie formatu, objętości i daty wydania.

Henryka Karolewska wnikliwie zbadała jednodniówkę pochodzą z 1895 roku $^{23}$, stanowiącą przejaw ambicji wydawniczych i zaangażowania inteligencji kaliskiej. Opracowanie Karolewskiej jest zarysem monograficznym, mającym na celu omówienie dziejów jednodniówki, analizę treści i zaprezentowanie sylwetek osób — zarówno zaangażowanych bezpośrednio w jej powstanie, jak i wspomnianych w treści artykułów. Książka uzupełniona indeksem i obszerną bibliografią, ilustrowana, wzbogacona informacjami na temat „Prosnej”, pochodzącymi z ówczesnej prasy, jest przykładem wyjątkowo rzetelnego opracowania.

Jednodniówka „Ćwierćpetit”, publikacja załogi Zakładów Graficznych „Książka i Wiedza” w Toruniu, wydana w 1952 roku z okazji Święta Pracy, stała się przedmiotem zainteresowania Wandy A. Ciszewskiej, służąc jako źródło informacji o życiu społecznym na początku lat 50 . XX wieku ${ }^{24}$. We wstępie krótko opisano jednodniówki jako typ dokumentów życia społecznego, podano ich cechy charakterystyczne, a następnie - szczegółowy opis formalny badanego wydawnictwa, informacje o układzie materiału, warstwie edytorskiej, komitecie redakcyjnym (m.in. spróbowano ustalić funkcje poszczególnych osób na podstawie listy pracowników Drukarni Toruńskiej). Omówiono wydawcę, uwzględniając historię i aspekty polityczne, dogłębnie przeanalizowano treść, uzupełniając znaczną ilością przytoczeń i cytatów, wyjaśniono genezę poszczególnych artykułów i znacznie tytułu. Analogicznym badaniom poddana została druga z jednodniówek Drukarni Toruńskiej ${ }^{25}$.

M. Korczyńska-Derkacz wykorzystała okolicznościową Jednodniówkę ku czci Juliusza Stowackiego jako źródło do przedstawienia działań organizacyjnych mających na celu sprowadzenie do Polski zwłok poety ${ }^{26}$. Jednodniówka z 1904 roku stanowiła apel do społeczeństwa o gromadzenie środków niezbędnych do realizacji tego projektu, poruszając jednocześnie temat wyboru miejsca ewentualnego pochówku. Analiza treści efemerydy, uzupełniona tłem historycznym dla wydarzeń w niej opisywanych, a w dalszej części - wykorzystanie prasy

22 Janusz KULIGOWSKI, „Próba Sił”- - jednodniówka Okręgowego Związu Młodzieży Wiejskiej w Mińsku Mazowieckim z 1920 r., Rocznik Mińskomazowiecki 2010, s. 84-118.

23 Henryka KAROLEWSKA, Kaliska jednodniówka „Prosna” i krąg jej autorów, Kalisz: Kaliskie Towarzystwo Przyjaciół Nauk 2010.

${ }^{24}$ Wanda A. CISZEWSKA, Ćwiercpetit. Jednodniówka załogi Zakładów Graficznych „Ksiązka i Wiedza” w Toruniu źródtem informacji o życiu społecznym na początku lat 50. XX w., Folia Toruniensia (11) 2011, s. 99-108.

25 Wanda A. CISZEWSKA, Efemeryda wydawnicza toruńskich drukarzy - Ćwierćpetit z roku 1953, Toruńskie Studia Bibliologiczne (9) 2012, s. 65-79.

26 M. KORCZYŃSKA-DERKACZ, Organizacja sprowadzenia zwłok Juliusza Stowackiego do Polski i jego pogrzeb na Wawelu w świetle Jednodniówki ku czci Juliusza Stowackiego z 1904 r. i prasy Krakowa z 1927 r., [w:] Kraków — Lwów: czasopisma XIX-XX wieku. T. 12. Pod red. Grzegorza Niecia, Grażyny Wrony, Kraków: Księgarnia Akademicka 2014, s. 63-77. 
krakowskiej z 1927 roku — pozwoliły na ciekawe zilustrowanie okoliczności prowadzących do złożenia zwłok Słowackiego na Wawelu.

W literaturze dotyczącej jednodniówek osobną grupę stanowią publikacje zajmujące się nimi pod kątem instytucji sprawczej lub środowiska wydawniczego. Odnotowano dziesięć tego typu opracowań ${ }^{27}$.

Z okazji sześćdziesięciolecia działalności Uniwersytetu Pedagogicznego im. Komisji Edukacji Narodowej w Krakowie Marek Glogier opublikował artykuł Czasopisma, biuletyny i jednodniówki w WSP/AP. Przegląd tytułów z lat 1951-2006, stanowiący uzupełnienie sporządzonego wcześniej przeglądu wydawnictw ciągłych ${ }^{28}$. Rejestr został stworzony w oparciu o kwerendę przeprowadzoną w archiwum uczelni, dotyczącą zgromadzenia inicjatyw dziennikarskich, publicystycznych i informacyjnych odzwierciedlonych w formie czasopism, biuletynów, jednodniówek, gazet, druków ulotnych i seryjnych ${ }^{29}$. Autor uwzględnił 45 tytułów, prezentując kolejno w układzie alfabetycznym wszystkie wydawnictwa, wśród których znalazło się sześć jednodniówek. Pochodziły z lat: 1959, 1975, 1980, 1992, 2002 i 2005, stanowiły inicjatywy różnych organizacji studenckich, m.in.: Koła Naukowego Polonistów (Pała. Satyryczny Organ Koła Naukowego Polonistów, 1959), KZ PZPR WSP (Opinie, 1975) i Koła Naukowego Bibliologów (Kiermasz, 1980).

Jednodniówkom wydanym w dwudziestoleciu międzywojennym przez działającą od 1924 roku Ligę Morską i Rzeczną, a następnie Ligę Morską i Kolonialną, zgromadzonym w zbiorach Biblioteki Narodowej, Biblioteki Jagiellońskiej i Zakładu Narodowego im. Ossolińskich swój artykuł poświęcił Adam Ruta ${ }^{30}$. Tematyka obejmowała szeroko pojęte zagadnienia morskie, promowanie floty, portu w Gdyni, rozwoju gospodarczego wybrzeża, cele i charakter Ligi, prezentację jej działalności oraz zachęcanie do edukacji morskiej. Na podstawie dziewięciu wydawnictw autor przedstawił ewolucję jednodniówek — zarówno w zakresie formy edytorsko-typograficznej, jak i zawartości treściowej.

Ten sam autor omówił również Czasopisma żeglarskie w Drugiej Rzeczpospolitej, opisując zbiór periodyków morskich, zdominowanych przez tematykę

27 Analizy dwóch publikacji dokonała Małgorzata Korczyńska-Derkacz (Jednodniówki jako..., s. 139-140): Ireneusz SIKORA, Jednodniówki Zwiazku Podhalan, Wierchy (40) 1980, s. 389-392; oraz Arkadiusz KOŁODZIEJCZYK, Jednodniówki strażackie Południowego Podlasia $i$ Wschodniego Mazowsza, [w:] Prasa Podlaska w XIX-XX wieku. Szkice i materiaty. T. II. Praca zbiorowa pod red. Dariusza Grzegorczuka i Arkadiusza Kołodziejczyka, Siedlce: IH AP 2004, s. 155-165.

28 Marek GLOGIER, Czasopisma, biuletyny i jednodniówki w WSP/AP, przegląd tytułów $z$ lat 1951-2006, Konspekt (2/3) 2006, s. 106-123.

29 Ibidem, s. 106.

30 Adam RUTA, Jednodniówki Ligi Morskiej i Kolonialnej, Rocznik Historii Prasy Polskiej (2) 2007 , s. 285-297. 
żeglarską ${ }^{31}$. Wśród nich znalazły się także jednodniówki wydane w latach 1923 1939 m.in. przez: Ligę Morską i Kolonialną, organizacje żeglarskie, wioślarskie, akademickie i harcerskie, uczniów Szkoły Morskiej. Na dziesięciu stronach w kolejności chronologicznej szczegółowo omówiono dziewiętnaście jednodniówek jako pojedyncze obiekty, a następnie jako zamknięty zbiór. Autor zwrócił uwagę na ich wartość informacyjną, zróżnicowany poziom i występujące w nich gatunki piśmiennicze. W opisach uwzględnione były: format, objętość, metoda powielania, nakład, paginacja i działy oraz informacje o warstwie ilustracyjnej (jeśli grafiki dotyczyły żeglarstwa - szczegółowo odwzorowane), składzie redakcji, drukarni, autorach. Analizę zawartości uzupełniły informacje o okolicznościach powstania poszczególnych tekstów, ich fragmenty oraz fotokopie okładek ${ }^{32}$.

W publikacji Polskie jednodniówki okresu międzywojennego jako źródto informacji o życiu młodzieży akademickiej Lwowa M. Korczyńska-Derkacz uwzględniła trzynaście efemeryd dotyczących głównie Kół Bratniej Pomocy, kolejnych rocznic ich istnienia, prezentacji dorobku i pełnionej funkcji, a w dalszej części - wydawnictw odnoszących się do różnych aspektów życia studenckiego członków lwowskich uczelni ${ }^{33}$. Przedstawione zostały na tle ówczesnej sytuacji we Lwowie, z silnym podkreśleniem stanu i organizacji życia naukowego. Mocno zaakcentowano cele wydawania kolejnych jednodniówek, m.in. wzbudzanie poczucia patriotyzmu i solidarności oraz uświadamianie o trudnej sytuacji materialnej młodzieży. Na podstawie analizy treści autorka ukazała złożoność i różnorodność środowiska akademickiego, funkcjonowanie organizacji studenckich, ich aktywność we Lwowie, jednocześnie podkreślając wartość badanego materiału dla historyków szkolnictwa czy socjologów. Zbiór został również oceniony pod względem edytorskim i typograficznym, zwrócono uwagę na rodzaje papieru, format i ceny.

Na tle historii Zgromadzenia Marianów Niepokalanego Poczęcia Najświętszej Maryi Panny na ziemiach polskich i ich szeroko pojętej działalności edukacyjnej, Krzysztof Trojan przybliżył jednodniówkę wydaną przez Juwenat 28 grudnia 1928 roku jako jedyną zachowaną z okresu działalności seminarium w Skórcu $\left(\right.$ lata 1926-1933) ${ }^{34}$. Informacje o pozostałych wydawnictwach Marianów zostały

31 A. RUTA, Czasopisma żeglarskie w Drugiej Rzeczypospolitej, Rocznik Historii Prasy Polskiej (1), s. 47-67.

32 Ibidem, s. 58-67.

33 M. KORCZYŃSKA-DERKACZ, Polskie jednodniówki okresu międzywojennego jako źródło informacji o życiu młodzieży akademickiej Lwowa, [w:] Kraków - Lwów, książki, czasopisma, biblioteki XIX i XX wieku. T. 9, cz. 2. Pod red. Haliny Kosętki, Barbary Góry, Ewy Wójcik, Kraków: Księgarnia Akademicka 2009, s. 205-218.

${ }^{34}$ Krzysztof TROJAN, Jednodniówki wydawane przez Juwenat Zgromadzenia Księży Marianów w Skórcu, [w:] Prasa podlaska w XIX-XXI wieku. Szkice i materiaty. T. 3. Pod red. Rafała Dmowskiego i Arkadiusza Kołodziejczyka, Siedlce: Inst. Historii Uniw. Przyrodniczo-Humanistycznego 2010, s. 167-179. 
podane jedynie szczątkowo. Treść trzydziestoczterostronicowej efemerydy przedstawiona została przez pryzmat założeń Zgromadzenia; 21 tekstów autorstwa 14 uczniów pogrupowano według poruszanych zagadnień: o tematyce maryjnej, nawiązujące do historii i duchowości Marianów, ukazujące szkolną rzeczywistość. Pomimo iż „wszystkie teksty zostały napisane ręcznie (bardzo staranna kaligrafia) i opatrzone w kunsztowne rysunki [...]”35, autor pominął dokładniejszą ocenę ich warstwy graficznej.

Magdalena Maliszewska przeprowadziła wywiad z Leszkiem Jaranowskim ${ }^{36}$ — drukarzem, kolporterem i redaktorem czasopisma „Hutnik”, które w maju 1980 roku podczas strajków w Kombinacie Metalurgicznym Huta im. Lenina zostało zastąpione cyklem jednodniówek. Ukazywały się wówczas codziennie — łącznie dziewięć numerów. Leszek Jaranowski opowiedział o trudnościach wynikających z częstotliwości wydawania, procesie gromadzenia informacji i przygotowania tekstów, kręgu autorskim, organizacji druku i kolportażu. Przedstawienie zagadnienia z perspektywy redaktora pozwala spojrzeć na jednodniówki w szerszym świetle; opis okoliczności i procesu ich powstawania dobitnie uświadamia wielką wartość informacyjną tych wydawnictw.

Rozdział 8 publikacji Między sensacją a nauką: obraz produktów krakowskiego wydawnictwa i koncernu prasowego Ilustrowany Kurier Codzienny (19101939) dotyczy jednodniówek ${ }^{37}$, o których Piotr Borowiec pisze: „Od końca 1932 roku, w ścisłej »konspiracji« redakcyjnej, wydawano tzw. tajną bibułę. Były to małe pisemka, przygotowywane z okazji jubileuszów czy imienin właścicieli lub redaktorów koncernu" 38 . Z efemeryd, których nakład ograniczany był do liczby osób pracujących w redakcji, do dnia dzisiejszego zachowały się tylko cztery, które zostały opisane chronologicznie z uwzględnieniem okazji i okoliczności wydania, formatu, objętości, reklam i szaty graficznej.

Znaczna wartość informacyjna jednodniówek zadecydowała o ich włączeniu do opracowania Janusza Mieczkowskiego Media mniejszości w procesach komunikowania społecznego — doświadczenia z zachodnich województw Polski ${ }^{39}$. Ukazujące się po 1945 roku wydawnictwa Stowarzyszenia Twórców i Przyjaciół Kultury Cygańskiej oraz wytwarzane w środowisku Łemków przedstawione zostały jako środki przekazu mniejszości etnicznych, a także medium łączące je z ludnością polską.

35 Ibidem, s. 173.

${ }^{36}$ Leszek JARANOWSKI, rozm. przepr. Magdalena MALISZEWSKA, Strajkowe jednodniówki „Hutnika”, Biuletyn Informacyjny Stowarzyszenia Sieć Solidarności (4) 2013, s. 4.

37 Piotr BOROWIEC, Między sensacją a nauka. Obraz produktów krakowskiego wydawnictwa i koncernu prasowego Ilustrowany Kurier Codzienny (1910-1939), Kraków-Rzeszów: Firma SAS 2005.

38 Ibidem, s. 289.

39 Janusz MIECZKOWSKI, Media mniejszości w procesach komunikowania społecznego — doświadczenia z terenu zachodnich województw Polski, Rocznik Lubuski (1) 2012, s. 119-134. 
Jednodniówki są doskonałym źródłem wiadomości na temat życia codziennego, pomagają odtworzyć dzieje lokalnych społeczności, stąd badacze chętnie jako kryterium doboru biorą pod uwagę miejsce wydania ${ }^{40}$.

Wiesława Konopelska wykorzystała cztery jednodniówki wydane w Czeladzi do omówienia aspektów pomijanych w oficjalnie wydawanych gazetach codziennych i periodykach ${ }^{41}$. W oparciu o Jednodniówkę z okazji 10-lecia Ogólnego Zwiąku Podoficerów Rezerwy R.P. Koła Czeladź (1938), Pamiętniki z okazji 30i 50-lecia Ochotniczej Straży Pożarnej w Czeladzi $(1937,1957)$ oraz Nasze myśli wydawnictwo Uniwersytetu Powszechnego z okazji trzydziestolecia istnienia (1933) odtworzyła znaczną część historii miasta, dokonała interpretacji nie tylko zamieszczonych teksów, lecz także reklam, wykazując ich wartość dla odtworzenia topografii miejsc i nastrojów społecznych tamtego okresu. Ogłoszenia reklamowe, zamieszczane w jednodniówkach, posłużyły za źródło do badań również dla M. Korczyńskiej-Derkacz ${ }^{42}$.

Druga część artykułu Joanny Edwarczyk Prasa Tucholi w latach 1920-1939 prezentuje charakterystykę redagowanych w mieście druków okolicznościowych oraz piśmiennictwa branżowego ${ }^{43}$. Cztery jednodniówki: ,Jednodniówka: Z okazji pobytu Prezydenta Rzeczypospolitej Polskiej Pana Stanisława Wojciechowskiego w Tucholi i Borach Tucholskich” (1924), „Humorystyczna Gazeta Weselna” (1925), „Czuwaj” (1928) i „Jednodniówka przygotowana przez pedagogów z Seminarium Nauczycielskiego" (1934) to jedyne tego typu wydawnictwa, które ukazały się w Tucholi w dwudziestoleciu międzywojennym. Choć w porównaniu do wydawnictw periodycznych autorka nie poświęciła im zbyt wiele miejsca, doceniła ich wartość informacyjną, zwłaszcza w zakresie tematyki regionalnej i aktualnych spraw mieszkańców.

${ }^{40}$ M. Korczyńska-Derkacz (Jednodniówki jako..., s. 138-140) uwzględniła trzy publikacje dotyczące jednodniówek wybranych według miejsca wydania: Jacek LACHENDRO, Jednodniówki w województwie krakowskim w latach 1918-1939, Rocznik Historii Prasy Polskiej (2) 2004, s. 49-75; Andrzej ROMANOWSKI, „Jednodniówki” polskie w W.M. Gdańsku w latach 1928-1938, Pomerania (6) 1977, s. 46-47; Krzysztof WOŹNIAKOWSKI, Wileńskie jednodniówki polskojęzyczne z października 1939 roku, [w:] idem, Prasa, kultura, wojna. Studia z dziejów czasopiśmiennictwa, kultury literackiej i artystycznej lat 1939-1945. Seria druga, Kraków: Wydaw. Naukowe Akademii Pedagogicznej 2005, s. 206-218.

41 Wiesława KONOPELSKA, Czeladzkie ,jednodniówki” świadectwem życia codziennego i odświętnego miasta, [w:] Oblicza mediów Śląska i Zagłębia Dąbrowskiego. T. 5. Pod red. Michała Kaczmarczyka i Dariusza Rotta, Sosnowiec: Oficyna Wydawnicza „Humanitas”, Wyższa Szkoła Humanitas 2011, s. 43-50.

${ }^{42}$ M. KORCZYŃSKA-DERKACZ, Reklamodawcy na łamach polskojęzycznych jednodniówek krakowskich z okresu międzywojennego (ze zbiorów CBN POLONA), mps.

43 Joanna EDWARCZYK, Prasa Tucholi w latach 1920-1939 (część 2), Toruńskie Studia Bibliologiczne (1) 2013, s. 9-21. 
Również jako istotne narzędzie komunikacji jednodniówki potraktowała Joanna Chojecka, skupiając się na drukach z terenu Włocławka ${ }^{44}$.

W 2013 roku A. Ruta opublikował problemowy artykuł dotyczący funkcjonowania jednodniówek w systemie krakowskiej cenzury w latach 1923-193945, w którym wykorzystał protokoły przesłuchań, protokoły rozpraw, odwołania i zażalenia oraz egzemplarze inkryminowanych druków ze śladami ingerencji cenzury. Kwerenda archiwalna akt sądowych z badanego okresu ujawniła 39 jednodniówek (siedem w języku hebrajskim i $32 \mathrm{w}$ języku polskim). Publikację uzupełniły dwa aneksy w formie tabel: spraw karnych przeciw redaktorom i drukarzom jednodniówek oraz konfiskat jednodniówek (z uwzględnieniem podstaw prawnych i wyroków), doskonale ilustrujące funkcjonowanie systemu kontroli prasy, a także stanowiące potwierdzenie znacznej roli jednodniówek.

Oprócz opracowań i artykułów problemowych powstają także publikacje bibliograficzne i katalogowe $\mathrm{e}^{46}$.

Bezsprzecznie najważniejszą z nich jest 16 tom Bibliografii polskiej 19011939, w całości poświęcony jednodniówkom ${ }^{47}$. Decyzja o takiej formie publikacji podyktowana była nie tylko specyficzną formą materiału i problemami związanymi z włączeniem go do regularnych tomów, lecz także świadomością wartości jednodniówek:

Wszakże, jednodniówki to niezmiernie interesujący typ publikacji. W pozornie niewielkich i nieznaczących broszurach (choć czasem o sporej objętości) utrwalano pamięć o bieżących wydarzeniach, ludziach, a także i wszelkiego rodzaju działalności. Zebrany materiał dowodzi, jak wiele instytucji i organizacji działających w pierwszej połowie XX wieku na ziemiach polskich podejmowało takie próby. Wydanie niewielkiej broszury, niekiedy w celach charytatywnych, było najpewniejszym i najprostszym, a być może i najmniej kosztownym sposobem na opisanie jakiegoś wydarzenia lub własnej działalności. Niejednokrotnie wydawano je również bardzo starannie pod względem edytorskim. Tak więc, są te wydawnictwa wyjątkowymi dokumentami swojej epoki ${ }^{48}$.

Wydawnictwo, przez autorów określone jako „eksperymentalne”, rejestruje 4796 pozycji, potraktowanych jako wydawnictwa zwarte: opisanych według normy opisu książki, z nazwiskami autorów i redaktorów podanymi w miejscu oznaczenia odpowiedzialności, z wprowadzeniem jednolitej formy pisowni ty-

44 Joanna CHOJECKA, Jednodniówki we Włocławku powstałe w latach 1946-2005, [w:] Media lokalne i sublokalne na Kujawach wschodnich i ziemi dobrzyńskiej. Pod red. Wiesława Końskiego, Włocławek: WSHE 2007, s. 267-274.

45 A. RUTA, Jednodniówki w systemie krakowskiej cenzury w latach 1923-1939, Toruńskie Studia Bibliologiczne (2) 2013, s. 167-188.

46 M. Korczyńska-Derkacz (Jednodniówki jako..., s. 140) scharakteryzowała kilka z nich, w tym: Andrzej PIWOWARCZYK, Bibliografia zawartości jednodniówek Stowarzyszenia Miłośników Zieleni Chetmskiej „Ziemia Chełmska” i innych okolicznościowych jednodniówek wydanych w latach 1960-1979, Chełm 1983.

47 Bibliografia polska 1901-1939, T. 16. Jednodniówki A-Ż. Red. Ewa Dombek, Hanna Machnik, Warszawa: Biblioteka Narodowa 2014.

48 Ibidem, s. VII. 
tułów. Maksymalnie dążono do autopsji egzemplarza; przy wyborze kolejności elementów tytułu kierowano się układem graficznym strony tytułowej, okładki lub nagłówka, będących podstawą opisu ${ }^{49}$. Włączone zostały: jednodniówki stanowiące pierwsze numery czasopism lub zapowiadające postanie czasopisma, jednodniówki publikowane pod różnymi tytułami, zastępujące kolejne numery czasopisma, druki uznane za jednodniówki ze względu na podobieństwo formy wydawniczej, niewielka grupa wydawnictw pamiątkowych oraz opisy przejęte ze źródeł, w takiej postaci, jak zarejestrowano je ówcześnie.

W ramach poszerzania wiedzy o ośrodku wydawniczym w Przemyślu, istniejącym od XVIII wieku, Emilia Długosz i Anna Siciak opracowały adnotowaną bibliografię jednodniówek przemyskich ${ }^{50}$. Opierając się na zbiorach bibliotek, archiwów, drukowanych bibliografiach, opracowaniach historycznych, bazach elektronicznych i prasie lokalnej, uwzględniono w niej 92 pozycje, w tym 77 w języku polskim. Adnotacje objęły spisy treści i szczegółowe informacje o zwartości, sigla bibliotek posiadających egzemplarze, a także informacje o publikacjach omawiających poszczególne jednodniówki. Zastosowano układ chronologiczny, uzupełniony indeksami: tytułów oraz nazwisk i pseudonimów autorów, redaktorów i nakładców.

Bibliografię jednodniówek ze zbiorów Biblioteki Śląskiej w Katowicach w układzie alfabetycznym zestawiły Magdalena Tomecka i Jolanta Sładek ${ }^{51}$. Wśród 777 pozycji znalazły się m.in. jednodniówki zakładów pracy, grup zawodowych, organizacji związkowych, społecznych, śpiewaczych, polonijnych, młodzieżowych i studenckich. Uwzględniono druki określane przez autorów jako jednodniówki oraz wydawnictwa okolicznościowe o cechach jednodniówki, natomiast pominięto jednodniówki zastępujące numery czasopism. Wart podkreślenia jest fakt, iż autorki — obok adnotacji treściowych — uwzględniły informacje o zamieszczanych reklamach.

Żydowskie druki ulotne, w tym także jednodniówki, zgromadzone w Zakładzie Dokumentów Życia Społecznego Biblioteki Narodowej stały się przedmiotem czterech zestawień bibliograficznych ${ }^{52}$. Najnowsze z nich — Palestyna $w$ żydowskich drukach ulotnych wydanych w II Rzeczpospolitej - opracowane przez Bar-

49 Ibidem, s. VIII-XI.

50 Emilia DŁUGOSZ, Anna SICIAK, Przemyskie jednodniówki: bibliografia adnotowana, Rocznik Historyczno-Archiwalny (22) 2010, s. 199-237.

51 Magdalena TOMECKA, Jolanta SŁADEK, Jednodniówki w zbiorach Biblioteki Ślaskiej, Katowice: Biblioteka Śląska 2012.

52 Trzy z nich opisała M. Korczyńska-Derkacz (Jednodniówki jako..., s. 141): Alina CAŁA, Zofia GŁOWICKA, Dokumenty życia społecznego Żydów polskich (1918-1939) w zbiorach Biblioteki Narodowej, Warszawa: Biblioteka Narodowa 1999; Barbara ŁETTOCHA, Aleksandra MESSNER, Alina CAŁA, Żydowskie druki ulotne w II Rzeczypospolitej w zbiorach Biblioteki Narodowej. T. 1, Warszawa: Biblioteka Narodowa 2004; A. CAŁA, Żydowskie periodyki i druki okazjonalne w języku polskim. Bibliografia, Warszawa: Biblioteka Narodowa 2005. 
barę Łętochę, Aleksandrę Messner, Alinę Całą i Izabelę Jabłońską — objęło 141 pozycji związanych z działalnością Żydów polskich na rzecz utworzenia siedziby narodowej ${ }^{53}$. Bogato ilustrowana bibliografia w układzie chronologicznym stanowi uzupełnienie kolekcji zaprezentowanej w poprzednich wydawnictwach ${ }^{54}$.

Również jednodniówki harcerskie znalazły swoje miejsce w zestawieniach bibliograficznych: Zenon Buczewski nakładem własnym w 1983 roku opublikował zestawienie czasopism harcerskich na świecie, które ukazały się po 1939 roku $^{55}$ wśród nich uwzględnił 41 jednodniówek, natomiast Marian Miszczuk i Wiesław Kukla do swojej bibliografii włączyli jednodniówki emigracyjne ${ }^{56}$.

Choć jednodniówki wciąż stanowią obszar słabo zbadany, coraz większa liczba badaczy zwraca uwagę na ich wartość źródłową i czyni z nich główny przedmiot swoich rozważań. Warto zwrócić uwagę, iż ilościowy rozwój literatury obserwujemy po 2000 roku. Spośród 46 zbadanych pozycji z lat 1970-1979 pochodzą dwie, tyle samo z lat 1990-1999, trzy z okresu 1980-1989, co stanowi niecałe $15 \%$. W pierwszej dekadzie XX wieku ukazało się 20 publikacji, a pozostałe $19-$ w ostatnim pięcioleciu. Jedną z przyczyn tak znacznego wzrostu jest bez wątpienia zwiększenie dostępu do jednodniówek w wyniku procesów digitalizacyjnych i włączania tych dokumentów do bibliotek cyfrowych ${ }^{57}$. Kształtuje się również pewna specjalizacja wśród naukowców: obok zespołów bibliotekarzy z BN i CBW, którzy opracowali po kilka wydawnictw, również M. Korczyńska-Derkacz oraz A. Ruta konsekwentnie zgłębiają problematykę jednodniówek.

53 B. ŁĘTOCHA, A. MESSER, A. CAŁA, Izabela JABŁOŃSKA, Palestyna $w$ żydowskich drukach ulotnych wydawanych w II Rzeczypospolitej, Warszawa: Biblioteka Narodowa 2009.

54 Podobnie, w wyniku pracy zespołowej, w latach 2005-2006 Centralna Biblioteka Wojskowa wydała trzy tematyczne katalogi jednodniówek ze swoich zbiorów, które uwzględniła w stanie badań M. Korczyńska-Derkacz (Jednodniówki jako..., s. 141): Jednodniówki w zbiorach Centralnej Biblioteki Wojskowej: katalog. Oprac. Beata Czekaj-Wiśniewska, Małgorzata Gwara, Magdalena Lewnau, Warszawa: Wydaw. Polonia Militaris 2005; W obronie niepodległości: jednodniówki poświęcone wojnie polsko-rosyjskiej 1919-1920 w zbiorach Centralnej Biblioteki Wojskowej: katalog. Oprac. iidem, Warszawa: Wydaw. Polonia Militaris 2006; Korpus Ochrony Pogranicza: jednodniówki w zbiorach Centralnej Biblioteki Wojskowej. Oprac. iidem, Warszawa: Wydaw. Polonia Militaris 2006.

55 Zenon BUCZEWSKI, Czasopisma harcerskie na świecie od 1939 roku, Vancouver: B.C. 1983.

56 Wiesław KUKLA, Marian MISZCZUK, Bibliografia harcerskich emigracyjnych i polonijnych druków zwartych, jednodniówek, kalendarzy i miscellanea wydanych w latach 1912-2004, Warszawa: Tomiko 2006.

${ }^{57}$ Najobszerniejszy zbiór jednodniówek dostępny jest w Cyfrowej Bibliotece Narodowej Polona. Jednocześnie są one włączane do zbiorów większości regionalnych bibliotek cyfrowych, m.in.: Kujawsko-Pomorskiej BC, BC Regionaliów Ziemi Łódzkiej, Mazowieckiej BC. Vide: CBN Polona, http://polona.pl [dostęp: 5 V 2016]; Kujawsko-Pomorska BC, http://kpbc.umk.pl/dlibra [dostęp: 5 V 2016]; BC Regionalia Ziemi Łódzkiej, http://bc.wimbp.lodz.pl/dlibra [dostęp: 5 V 2016]; Mazowiecka BC, http://mbc.cyfrowemazowsze.pl/dlibra [dostęp: 5 V 2016]. 
KATARZYNA JAMROZIK

\section{RESEARCH INTO OCCASIONAL DAILIES IN POLAND AFTER 2008}

\section{Summary}

In recent years scholars have become increasingly drawn to publications documenting the life of society. Manifestations of this growing interest include an international conference devoted to such publications and organised in October 2004 by the Institute of Library and Information Science, University of Wrocław. The participants discussed the subject of occasional dailies, unique documents somewhere between non-periodical and serial publications. Numerous papers devoted to such publications were written by Małgorzata Korczyńska-Derkacz, who in 2008 presented the state of research into occasional dailies and carried out their multifaceted assessment as source materials, using the data from the Central Catalogue of Polish Periodicals. The present paper complements and continues the research carried out earlier.

The topics most frequently tackled by scholars include those devoted to specific titles, historical periods (occasional dailies in the inter-war period), places of publication (Lviv, Kraków), publishing institution or milieu (firefighters, students, scouts), ethnic groups (Jewish dailies). Few scholars have tackled dailies from the point of view of their untypical editorial and formal features (periodical or non-periodical publication) and the related problems with their formal and substantive description. The fact that occasional dailies have been incorporated into the collections of digital libraries and the growing number of bibliographic compilations, including Volume 16 of the Polish Bibliography 1901-1939 devoted entirely to such publications, stimulate the interest of historians of the press, linguists, sociologists, ethnographers, culture scholars, historians of social movements, politics and economy, historians studying the customs and traditions of various ethnic and professional groups, localities and education. They appreciate such publications as a unique source of historical and factual information (lists of people, tables and plates, photographs, statutes etc.).

KEY WORDS: press studies, ephemera, occasional publications, publications documenting society's life 